\title{
CYLINDRICAL SHELL ANALYSIS OF REACTOR PRESSURE VESSEL FOR RDE
}

\section{ANALISIS SEL SILINDER BEJANA TEKAN REAKTOR UNTUK RDE}

\author{
Sri Sudadiyo \\ Center for Nuclear Reactor Technology and Safety - BATAN \\ Puspiptek Area Building 80, Tangerang 15310 \\ E-mail address: sudadiyo@batan.go.id
}

Received 22 December 2018, Received in revised form 29 November 2020, Accepted 25 December 2020

\begin{abstract}
CYLINDRICAL SHELL ANALYSIS OF REACTOR PRESSURE VESSEL FOR RDE. This study deals with the analysis of cylindrical shell design for Reactor Pressure Vessel (RPV) of Reaktor Daya Eksperimental (RDE). The RDE is developed by BATAN as the preliminary of nuclear technology in Indonesia. RPV is a container for confining helium gas at pressure (3 MPa) and temperature (circa $250{ }^{\circ} \mathrm{C}$ ). In reactor operation, mechanical stresses act to the RPV as in consequence of internal pressure, external pressure, and different loads due to dead weight and helium content load. Therefore, if the RPV could not retain its material strength it will cause failure. The applications and validity of Fortran code (RPV_RDE.exe) for the design analysis are represented by two simulation cases, which show good calculation results of design outputs compared to analytical solutions by hand calculations. Design outputs have met the safety requirements (on ultimate tensile strength $485 \mathrm{MPa}$ ) for the minimum wall thickness of cylindrical shell in upper portion of $60 \mathrm{~mm}$ with Hoop stress $104.47 \mathrm{MPa}$ and in lower portion of $100 \mathrm{~mm}$ with Hoop stress $62.81 \mathrm{MPa}$, respectively.
\end{abstract}

Keywords: RDE, reactor pressure vessel, cylindrical shell, Fortran code, mechanical stresses

\section{ABSTRAK}

\begin{abstract}
ANALISIS SEL SILINDER BEJANA TEKAN REAKTOR UNTUK RDE. Penelitian ini berkaitan dengan analisis dari desain sel silinder untuk bejana tekan reaktor (Reactor Pressure Vessel / RPV) dari Reaktor Daya Eksperimental (RDE). RDE dikembangkan oleh BATAN untuk kehadiran teknologi nuklir di Indonesia. RPV adalah wadah untuk membatasi gas helium pada tekanan (3 MPa) dan suhu (sekitar $250{ }^{\circ} \mathrm{C}$ ). Dalam operasi reaktor, tekanan mekanis terjadi terhadap RPV sebagai akibat dari tekanan internal, tekanan eksternal, dan beban yang berbeda akibat berat mati dan beban helium. Oleh karena itu, jika RPV tidak dapat mempertahankan kekuatan materialnya maka akan menyebabkan kegagalan. Aplikasi dan validitas kode Fortran (RPV_RDE.exe) untuk analisis desain diwakili oleh dua kasus simulasi, yang menunjukkan hasil perhitungan yang baik dari luaran desain dibandingkan dengan solusi analitis dengan kalkulasi tangan. Luaran desain telah memenuhi persyaratan yang aman (pada kekuatan tarik tertinggi $485 \mathrm{MPa}$ ) untuk ketebalan dinding minimum sel silinder di bagian atas 60 mm dengan tegangan Hoop 104,47 MPa dan di bagian bawah $100 \mathrm{~mm}$ dengan tegangan Hoop 62,81 MPa.
\end{abstract}

Kata kunci: RDE, bejana tekan reaktor, sel silinder, kode Fortran, tegangan mekanik

\section{INTRODUCTION}

$\mathrm{R}$ eactor pressure vessel (RPV) is a very important equipment in engineering industries such as nuclear power plants including in Reaktor Daya Eksperimental (RDE). The RDE is developed by BATAN to be a basic reference and milestone of Indonesia in a nuclear power technology presence in the future [1]. This paper reviews (or notices) state of the art application of RDE in the preliminary design of RDE program that was introduced to the Agency for National Development Planning in the past year of 2014 [2]. The cylindrical shell constitutes structural components of RPV for RDE. This cylindrical shell of RPV is composed of the upper and lower portions $[1,3]$. The RPV has to be designed accurately to cope with the operational pressure and temperature. Moreover, RPV components are subjected to neutron irradiation of material during the operation of nuclear power plant [4-8]. In order to avoid this material failure, iterative calculations of design process analysis need to be conducted for determining geometry and dimensions of the RPV. A source code has been written in Fortran language (by using the Digital Visual Fortran Edition 6.0) and the various design calculations of RPV design can be implemented on a personal computer. 
The purpose of this paper is to compute the configuration (in the form of the model geometry and dimensions) of the cylindrical shell and to analyse the stresses on the RPV design in RDE. Material property data values are obtained from Section III of ASME standards to be used in subsequent design process analysis using a conservative method of mechanical stresses. Design process analysis for mechanical stresses of RPV configuration is conducted by calculating shear stress, longitudinal stress, and tangential stress induced by helium pressure. In this paper, the RPV of RDE is designed by studying in general high temperature gas-cooled reactors, especially main thermal parameters of the HTR-10 type as a reference for nuclear power plants $[1,4]$. The execution of Fortran code is expected to be able to rapidly compute the cylindrical shell configurations in the form of the model geometry and dimensions for the RPV repeatedly.

\section{METHODOLOGY}

Fig. 1 shows the general design of RPV for RDE with thermal power of $10 \mathrm{MW}$ [1]. The nuclear reactor core heat will achieve a high temperature of about $700{ }^{\circ} \mathrm{C}[1,9]$. This heat is then transferred to helium coolant within the reactor core after going through graphite. But helium gas is in contact with the inner wall of RPV which has a temperature of approximately $250^{\circ} \mathrm{C}$ under pressure of $3 \mathrm{MPa}[1,9]$. Table 1 denotes thermodynamic of an operational condition for RPV $[1,9]$.

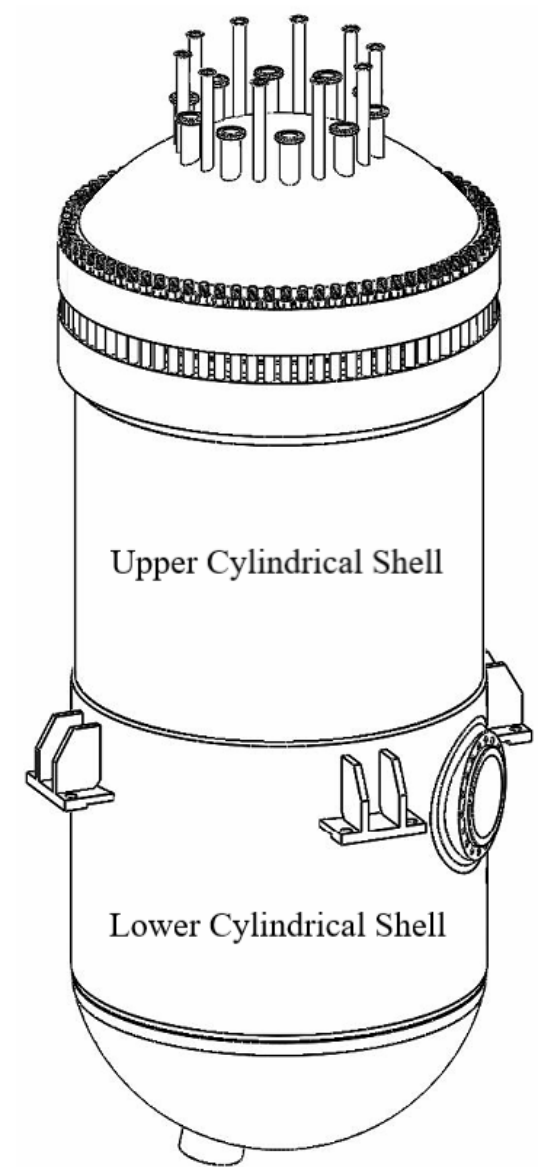

Figure 1. The view of reactor pressure vessel for RDE [1]. 
Table 1. Thermodynamic parameters of RPV for RDE.

\begin{tabular}{lll}
\hline Parameter & Unit & Value \\
\hline Inlet temperature of helium coolant $\left(T_{i}\right)[1,8]$ & ${ }^{\circ} \mathrm{C}$ & 250 \\
Outlet temperature of helium coolant $\left(T_{0}\right)[1,8]$ & ${ }^{\circ} \mathrm{C}$ & 700 \\
Flow rate of helium coolant $(m)[8]$ & $\mathrm{kg} / \mathrm{s}$ & 4.27 \\
Pressure of helium coolant $\left(P_{i}\right)[1,8]$ & $\mathrm{MPa}$ & 3 \\
Design pressure $\left(P_{d}\right)[1]$ & $\mathrm{MPa}$ & 3.6 \\
Design temperature $\left(T_{d}\right)[1]$ & ${ }^{\circ} \mathrm{C}$ & 371 \\
\hline
\end{tabular}

The following are some formulas of mechanical stresses involved in design calculations of RPV for RDE. The maximum shear stress $(\tau)$ can be written as $[10,11]$ :

$$
\tau=\frac{\sigma_{y}}{2}
$$

where $\sigma_{y}$ represents the yield strength of candidate materials.

Longitudinal stress $(\sigma)$ is given by [10]:

$$
\sigma_{L}=\frac{P_{i} R_{i}^{2}-P_{o} R_{o}^{2}}{R_{o}^{2}-R_{i}^{2}}
$$

Hoop stress $\left(\sigma_{H}\right)$ at any radius $R$ can be expressed as [10,12]:

$$
\sigma_{H}=\frac{P_{i} R_{i}^{2}-P_{o} R_{o}^{2}-\frac{R_{i}^{2} R_{o}^{2}\left(P_{o}-P_{i}\right)}{R^{2}}}{R_{o}^{2}-R_{i}^{2}}
$$

Radial stress $\left(\sigma_{R}\right)$ at any radius $R$ can be expressed as $[10,12]$ :

$$
\sigma_{R}=\frac{P_{i} R_{i}^{2}-P_{o} R_{o}^{2}-\frac{R_{i}^{2} R_{o}^{2}\left(P_{i}-P_{o}\right)}{R^{2}}}{R_{o}^{2}-R_{i}^{2}}
$$

where $P_{i}$ denotes internal pressure [MPa] of cylindrical shell or operational pressure of helium coolant, $P_{0}$ denotes external pressure [MPa] of cylindrical shell, $R_{i}$ is inner radius [m], $R_{o}$ is outer radius [m], and $R$ is radius [m] at point of interest.

For isotropic materials, shear modulus is given by using the following equation [10]:

$$
G=\frac{E}{2(1+v)}
$$

where $E$ is elasticity modulus or Young's modulus [GPa] and $v$ is Poisson's ratio.

Fig. 2 is the cross section of the cylindrical shell for RPV which will be used for design analysis of the upper cylindrical shell portion and lower cylindrical shell portion. The magnitude of the mechanical stresses can be determined by considering a free body diagram of the cross section, including its pressurized internal helium. The helium gas is assumed to have a negligible weight. Cold helium pressure within a gap (between outer reactor core barrel wall and inner RPV wall) of the RPV is $3 \mathrm{MPa}$ and its temperature is about $250{ }^{\circ} \mathrm{C}$. This temperature 
Jurnal Iptek Nuklir Ganendra

Ganendra Journal of Nuclear Science and Technology

Vol. 24 No. 1, January 2021: 1-10

corresponds to design pressure, and it is maintained in the RPV materials for the specified operation. Inside pressure (or helium pressure) is normally greater than the outside pressure (or containment pressure) [1, 13-15].

Materials selected for upper cylindrical shell and lower cylindrical shell of the pressure vessel components are carbon steel SA516-70, according to section III of ASME standards for higher temperature services [16,17]. Table 2 shows the material specification including chemical composition and mechanical property requirements for carbon steel plates at design temperature of $371^{\circ} \mathrm{C}[1]$.

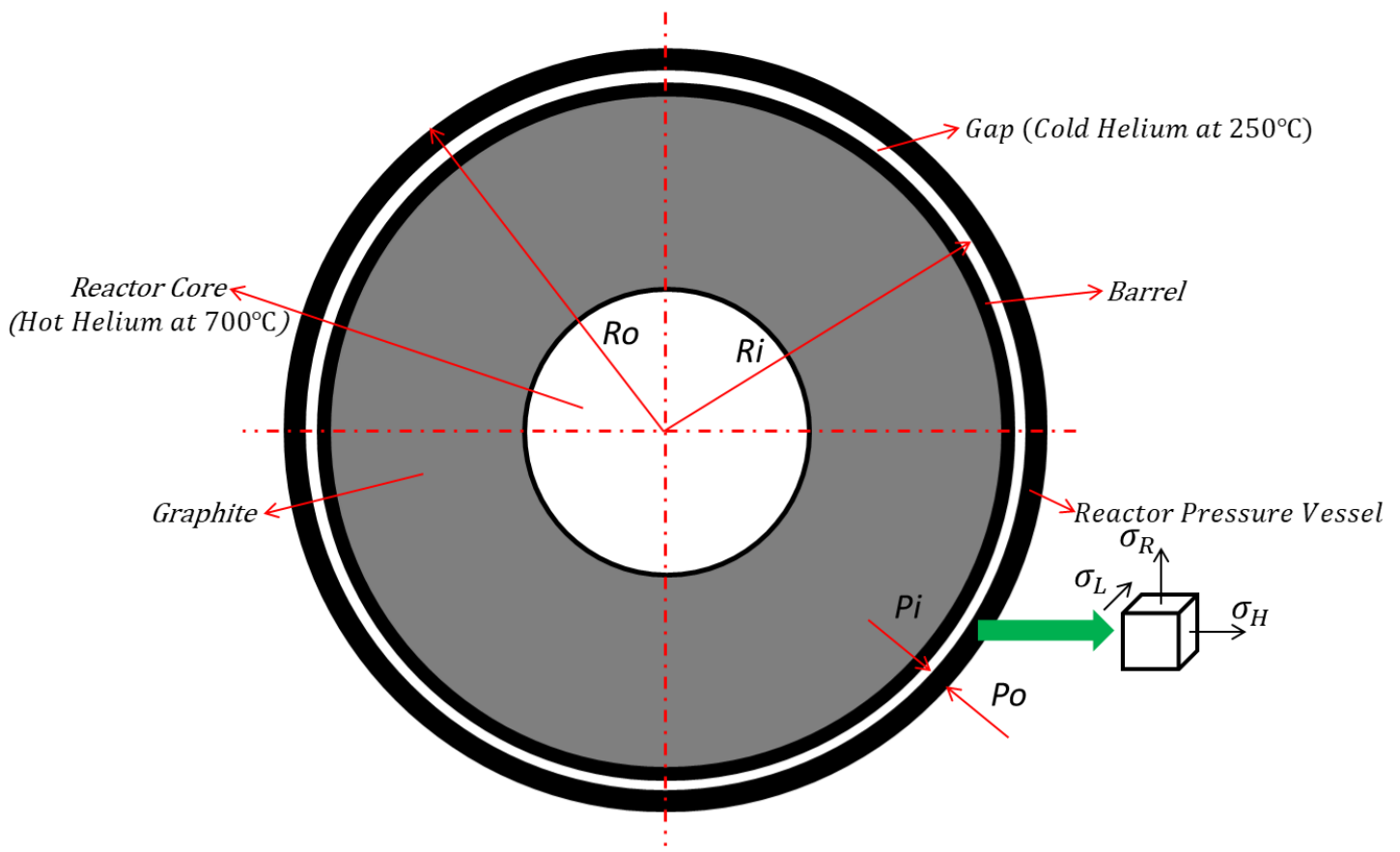

Figure 2. Cross section for cylindrical shell.

Table 2. Material specifications for SA516-70 plate at $371^{\circ} \mathrm{C}[16]$.

\begin{tabular}{lll}
\hline Parameter & Unit & Value \\
\hline Carbon, max. & $\%$ & 0.22 \\
Manganese, max. & $\%$ & 1 \\
Silicon, max. & $\%$ & 0.45 \\
Nickel, max. & $\%$ & 0.43 \\
Chromium, max. & $\%$ & 0.34 \\
Sulfur, max. & $\%$ & 0.018 \\
Phosphorus, max. & $\%$ & 0.015 \\
Copper, max. & $\%$ & 0.12 \\
Vanadium, max. & $\%$ & 0.06 \\
Yield strength & $\mathrm{MPa}$ & 260 \\
Ultimate tensile strength & $\mathrm{MPa}$ & 485 \\
Young's modulus & $\mathrm{GPa}$ & 200 \\
Poisson's ratio & - & 0.29 \\
\hline
\end{tabular}




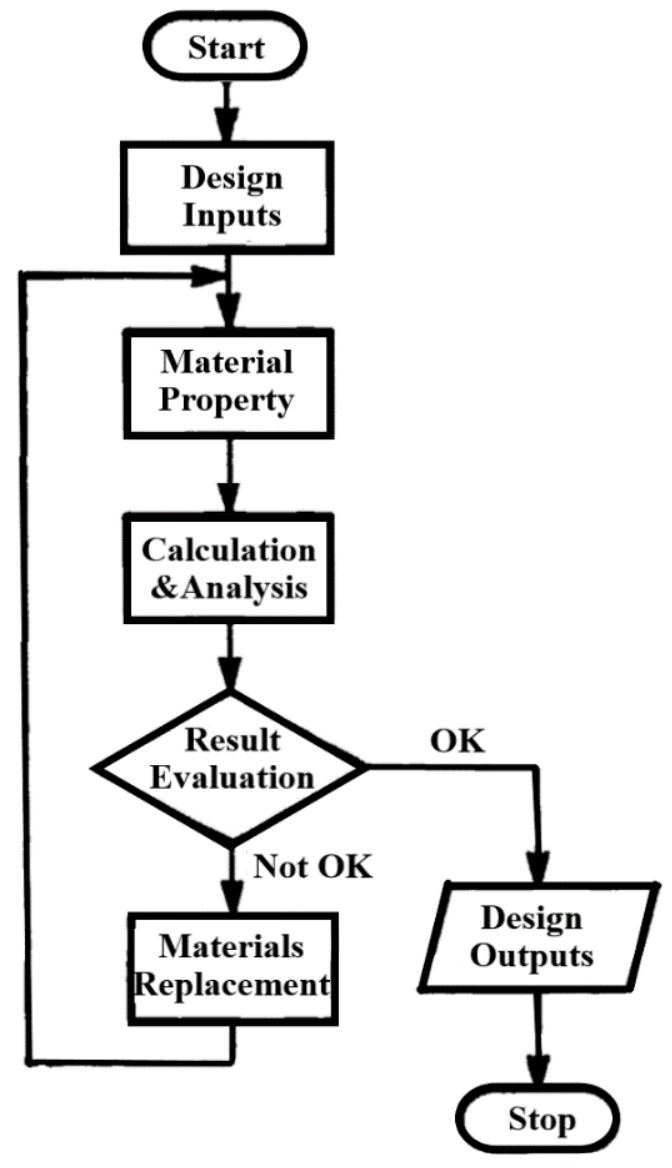

Figure 3. Flowchart for design process analysis of cylindrical shell.

Fig. 3 depicts a calculation procedure for design analysis of RPV cylindrical shells. Design inputs are composed of the ratio of predicted outer radius to inner radius on wall circle; the ratio of the assumed elastic region limitation over wall thickness; the intensity of inside pressure or helium pressure; and material property specifications of carbon steel SA516-70 referring to ASME standards. Calculation and analysis are the simulation steps by using the Equations (1) to (5) above. Result evaluation of mechanical stresses is then compared to maximum shear stress of materials. Materials replacement is done by substituting component materials, thus changing its mechanical properties. However, in the present paper it is shown only for carbon steel SA516-70. Design outputs are determined in the form of the model geometry and dimensions of the cylindrical shell of RPV.

\section{RESULTS AND DISCUSSIONS}

In the present study, analysis for the RPV design is imposed to upper cylindrical shell and lower cylindrical shell which are performed for helium pressure acting on the inner RPV wall at a gap. The minimum wall thickness or maximum allowable operational pressure (design pressure) of cylindrical shell must be designed with a greater thickness or lower operational pressure. As previously mentioned, analytical relationships in Equation (1) to Equation (5) can be applied for determining the cylindrical shell configurations in the form of geometry and dimensions for RPV of the RDE. The equations above are frequently used to compute mechanical stresses occurred on a given design inputs. Therefore, in order to speed up the calculations within the RPV design, the Fortran code (filename of RPV_RDE.exe) can be run on personal computers. This code has been verified against the analytical solutions (by hand calculations) which resulted in the cylindrical shell analysis including the upper portion and lower portion based on the Equations (1) to (5). Fig. 4 shows the validation results for Fortran code and analytical calculations. It can be seen that the results are very similar. 
Jurnal Iptek Nuklir Ganendra

Ganendra Journal of Nuclear Science and Technology

Vol. 24 No. 1, January 2021: 1-10

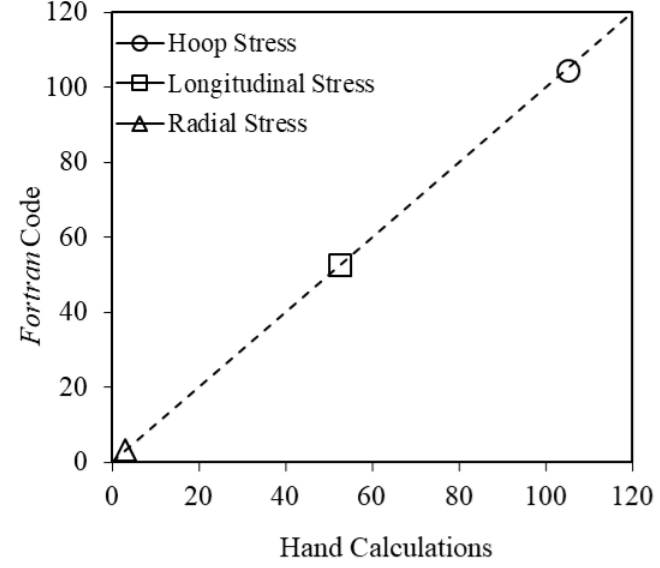

a)

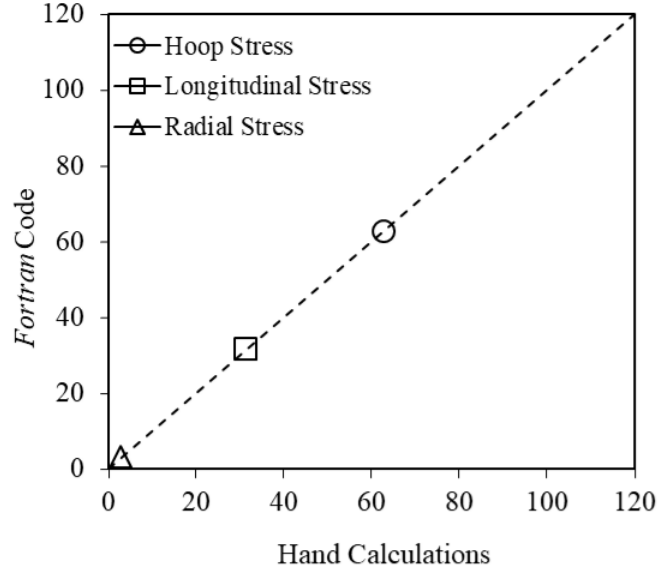

b)

Figure 4. Comparison of calculation results for cylindrical shell of: a) upper portion; b) lower portion.

Table 3. Result for various types of loads on RPV components of RDE.

\begin{tabular}{|c|c|c|c|c|c|c|c|}
\hline \multirow[b]{2}{*}{ Components } & \multicolumn{2}{|c|}{ Pressure [MPa] } & \multirow{2}{*}{$\begin{array}{l}\text { Weight } \\
\text { [ton] }\end{array}$} & \multirow[b]{2}{*}{ Volume $\left[\mathrm{m}^{3} / \mathrm{s}\right]$} & \multicolumn{3}{|c|}{ Mechanical Stresses [MPa] } \\
\hline & $\begin{array}{l}\text { Interna } \\
\text { I }\end{array}$ & $\begin{array}{l}\text { Extern } \\
\text { al }\end{array}$ & & & $\sigma_{H}$ & $\sigma_{\mathrm{L}}$ & $\sigma_{\mathrm{R}}$ \\
\hline $\begin{array}{l}\text { Upper cylindrical } \\
\text { shell }\end{array}$ & 3 & 0.05 & 3.6 & 0.632 & 104.47 & 52.23 & 2.95695 \\
\hline $\begin{array}{l}\text { Lower cylindrical } \\
\text { shell }\end{array}$ & 3 & 0.05 & 5.23 & 0.918 & 62.81 & 31.4 & 2.92843 \\
\hline
\end{tabular}

Various types of loads on cylindrical shell are shown in Fig. 2: (a) internal and external pressures; (b) dead weight of cylindrical shell; (c) helium gas content load of filling volume; and (d) loads in the tangential, axial, and radial directions. the load in the radial direction is compressive stress on the wall thickness of the cylindrical shell. Any combination of the above loading can be considered and located at any position on upper cylindrical shell or lower cylindrical shell. Moreover, other types of loadings not mentioned above can be considered if the effect can be simulated by combination of different loading types. For instance, a moment load can be simulated by combining two loads of equal magnitude but opposite in directions. In the following, results of loads will be given to show the accuracy of Fortran code of RPV_RDE.exe, as seen in Table 3. The results are iterative calculations (with matrix dimensions of 10000 elements for variable array) of design analysis for getting the values of minimum wall thickness of upper cylindrical shell $(60 \mathrm{~mm})$ and lower cylindrical shell $(100 \mathrm{~mm})$ based on the ratio of outer radius to inner radius of 1.029 and 1.048 , respectively.

Following the foregoing calculation procedure given by Fig. 3 for design analysis of RPV cylindrical shells, the Equations (1) to (5) are derived by assuming the elastic state of stress and constant material properties which are independent of the position and temperature. The cylindrical shell wall temperature varies in the radial direction while the temperatures in the axial and tangential directions are assumed to remain constant. In this preliminary design of RPV, the temperature changes in the axial direction (in the longitudinal direction) are negligible compared to the radial direction on steady state heat conduction for wall thickness. In addition, for one-dimensional conduction, a uniform temperature on the perimeter of the cylindrical shell is considered to occur for helium gas in a vertically attached RPV gap. For analytical solution (by hand calculation), the mechanical stresses at the cylindrical shell are calculated according to the Equations (2) to (4). Hoop stress on the Equation (3) is based on the superposition principle, which in turn can be used for solving linear problems. This means that the material properties being used are independent of the temperature which remains constant throughout the analysis. Fig. (5) and (6) show the RPV_RDE.exe execution for model geometry and dimensions of upper cylindrical shell and lower cylindrical shell at the outer radius, respectively. 


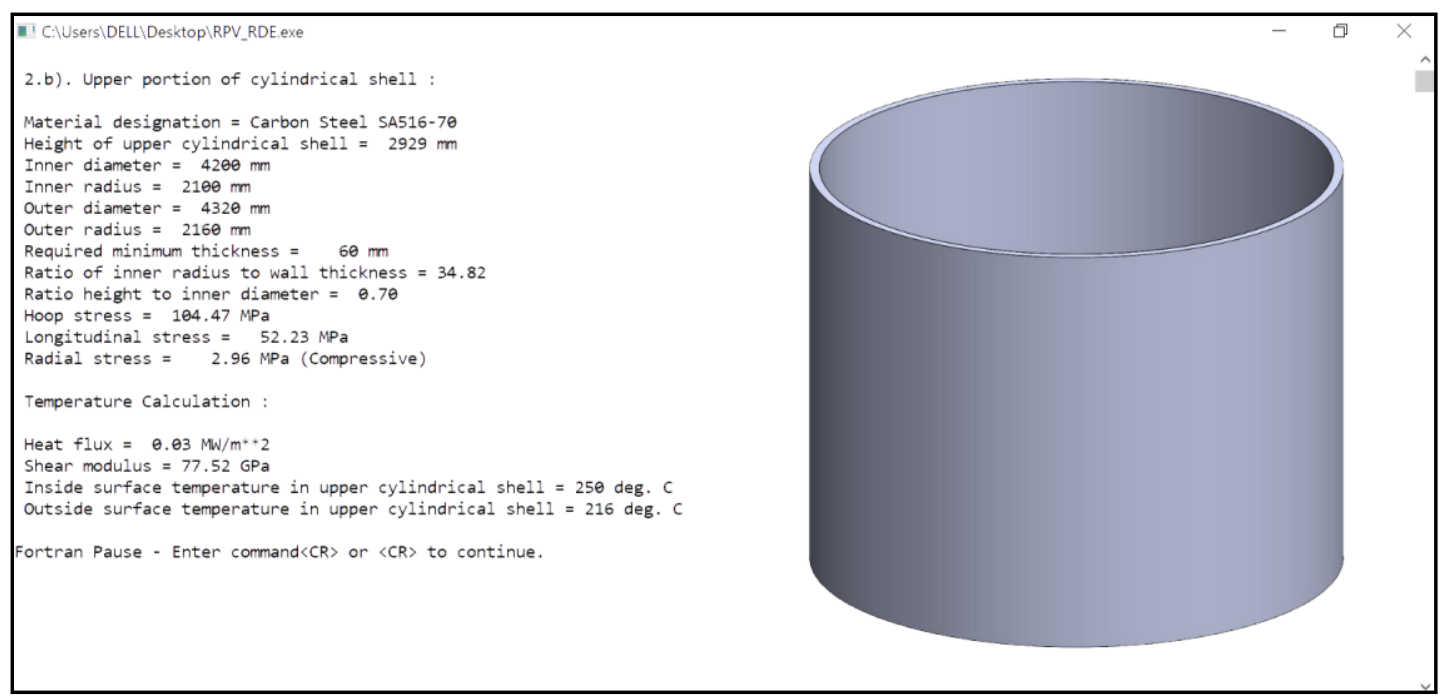

Figure 5. Partial execution of $R P V \_R D E$.exe for design calculations of upper cylindrical shell.

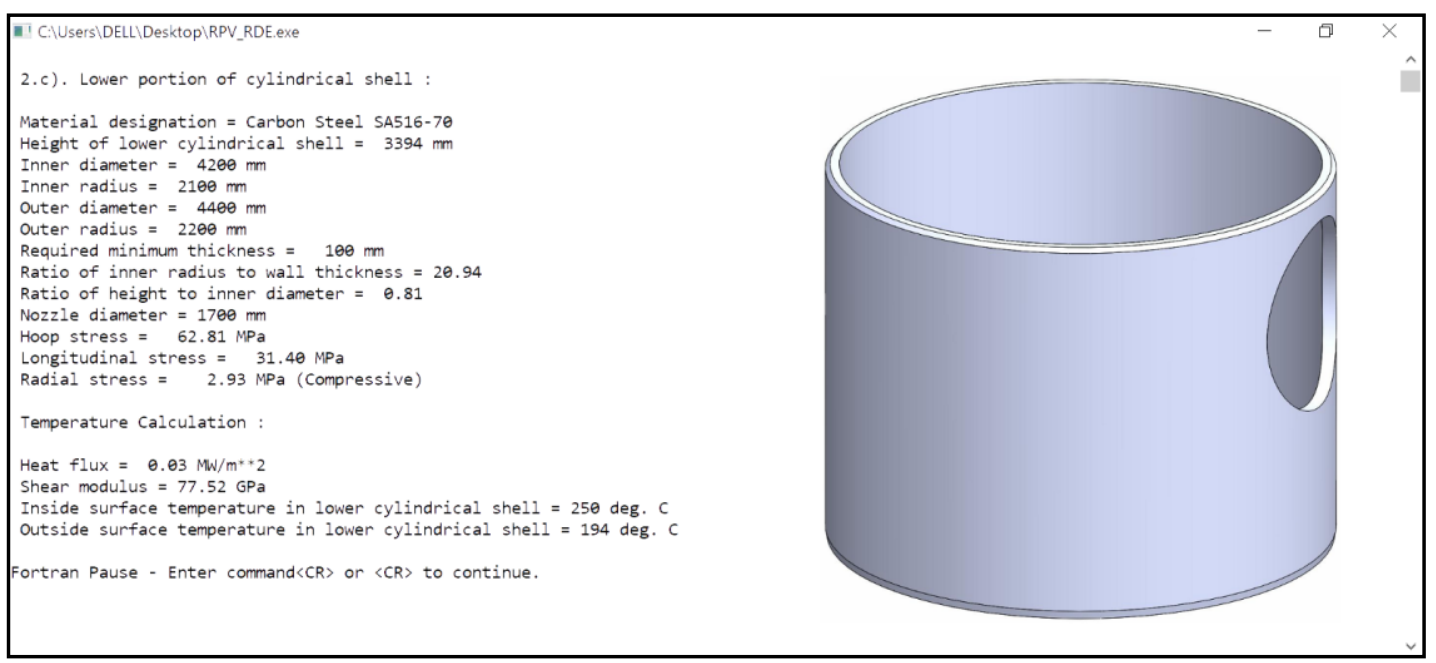

Figure 6. Partial execution of RPV_RDE.exe for design calculations of lower cylindrical shell.

Using the maximum shear stress of $130 \mathrm{MPa}$, the mechanical stresses acting on the upper and lower cylindrical shells are shown in Fig. 5 and 6, respectively. The Hoop stress of the upper cylindrical shell is 104.47 $\mathrm{MPa}$ for wall thickness of $60 \mathrm{~mm}$ (as in Fig. 5) and Hoop stress of the lower cylindrical shell is $62.81 \mathrm{MPa}$ for wall thickness of $100 \mathrm{~mm}$ (as in Fig. 6). Hence, the constraints of the Equations (2) to (4) as represented above is also satisfied under the value of shear modulus of the Equations (5). Furthermore, design calculations are based on design pressure (3.6 MPa) and will be analysed for two simulation cases. For the first case, a circular section of an upper cylindrical shell with a radius of $2100 \mathrm{~mm}$ and wall thickness of $60 \mathrm{~mm}$ has been modelled, as shown in Fig. 5. The upper cylindrical shell is made of carbon steel SA516-70 with modulus of elasticity of $200 \mathrm{GPa}$ and Poisson's ratio of 0.29 . The circular section is varied into 6 thicknesses in radial direction. The results of mechanical stresses are shown in the Table 4. For the second case, a circular section of a lower cylindrical shell with a radius of 2100 $\mathrm{mm}$ and wall thickness of $100 \mathrm{~mm}$ has also been modelled, as shown in the Fig. 6 . The selected material of lower cylindrical shell is the same as that used for the upper cylindrical shell. The circular section is also varied into 6 thicknesses in radial direction. The results of mechanical stresses are shown in the Table 5 . In Tables 4 and 5, all of radial stresses are compressive. Those results (in the Tables 4 and 5) show that the simulation results of $R P V \_R D E$.exe are very close to the values of analytic solution with a maximum discrepancy value of about 0.28 (= $70 \mathrm{MPa}-69.72 \mathrm{MPa}$ ) for Hoop stress on thickness of $90 \mathrm{~mm}$ at the lower cylindrical shell of RPV components of RDE. It should be noted that radial stress values increase with the wall thickness because the external pressure is assumed to be fixed (at $0.05 \mathrm{MPa}$ ) in the hand calculations. 
Jurnal Iptek Nuklir Ganendra

Ganendra Journal of Nuclear Science and Technology

Vol. 24 No. 1, January 2021: 1-10

Table 4. Simulation results for upper cylindrical shell on RPV components of RDE.

\begin{tabular}{lllllll}
\hline & \multicolumn{5}{c}{ Mechanical Stresses [MPa] } \\
\cline { 2 - 7 } $\begin{array}{l}\text { Designed } \\
\text { Thickness } \\
{[\mathrm{mm}]}\end{array}$ & \multicolumn{2}{c}{ Fortran Code of $R P V \_R D E . e x e$} & \multicolumn{2}{c}{ Analytic Solutions by hand calculations } \\
\cline { 2 - 7 } & $\begin{array}{c}\text { Hoop } \\
\text { Stress }\end{array}$ & $\begin{array}{c}\text { Longitudinal } \\
\text { Stress }\end{array}$ & $\begin{array}{c}\text { Radial } \\
\text { Stress }\end{array}$ & $\begin{array}{c}\text { Hoop } \\
\text { Stress }\end{array}$ & $\begin{array}{c}\text { Longitudinal } \\
\text { Stress }\end{array}$ & $\begin{array}{c}\text { Radial } \\
\text { Stress }\end{array}$ \\
\hline 55 & 114.55 & 57.27 & 2.96073 & 115 & 57.52 & 2.97119 \\
56 & 112.5 & 56.25 & 2.96001 & 112.92 & 56.49 & 2.97169 \\
57 & 110.53 & 55.26 & 2.9593 & 110.91 & 55.48 & 2.97216 \\
58 & 108.62 & 54.31 & 2.95859 & 108.98 & 54.51 & 2.97263 \\
59 & 106.78 & 53.39 & 2.95787 & 107.11 & 53.58 & 2.97307 \\
60 & 104.47 & 52.23 & 2.95695 & 105.3 & 52.67 & 2.9735 \\
\hline
\end{tabular}

Table 5. Simulation results for lower cylindrical shell on RPV components of RDE.

\begin{tabular}{lllllll}
\hline & \multicolumn{5}{c}{ Mechanical Stresses [MPa] } \\
\cline { 2 - 6 } $\begin{array}{l}\text { Designed } \\
\text { Thickness } \\
{[\mathrm{mm}]}\end{array}$ & \multicolumn{5}{c}{ Fortran Code of RPV_RDE.exe } & Analytic Solutions by hand calculations \\
\cline { 2 - 7 } & $\begin{array}{l}\text { Hoop } \\
\text { Stress }\end{array}$ & $\begin{array}{l}\text { Longitudina } \\
\text { I Stress }\end{array}$ & $\begin{array}{l}\text { Radial } \\
\text { Stress }\end{array}$ & $\begin{array}{l}\text { Hoop } \\
\text { Stress }\end{array}$ & $\begin{array}{l}\text { Longitudina } \\
\text { I Stress }\end{array}$ & $\begin{array}{l}\text { Radial } \\
\text { Stress }\end{array}$ \\
\hline 50 & 126 & 63 & 2.9643 & 126.64 & 63.35 & 2.96842 \\
60 & 104.47 & 52.23 & 2.95716 & 105.3 & 52.67 & 2.9735 \\
70 & 90 & 45 & 2.95003 & 90.05 & 45.05 & 2.97713 \\
80 & 78.75 & 39.38 & 2.9429 & 78.62 & 39.33 & 2.97985 \\
90 & 70 & 35 & 2.93577 & 69.72 & 34.89 & 2.98197 \\
100 & 62.81 & 31.4 & 2.92843 & 62.61 & 31.33 & 2.98366 \\
\hline
\end{tabular}

The above simulation results are then further evaluated with literatures $[18,19]$ on reactor pressure vessel analysis to compare the design calculations as shown in Fig. 7. It should be noted that detailed overview for design calculations are given in the literatures $[18,19]$ which are part of the references of this article, although the analysis on the cylindrical shell of RPV was not well described. Moreover, model geometry and dimensions were also not provided; there were no figures and description of the RPV. However, these references are available at the websites on internet repositories so that the author could utilize the methodologies from formulas given by these references. In order to have a reliable validation, the calculation analysis of cylindrical shells need to have all data of the selected material (carbon steel SA516-70). Based on the evaluation as plotted in Fig. 7 with a) for upper portion and b) for lower portion, calculation results (Hoop, longitudinal, and radial stresses) are sufficiently described. 


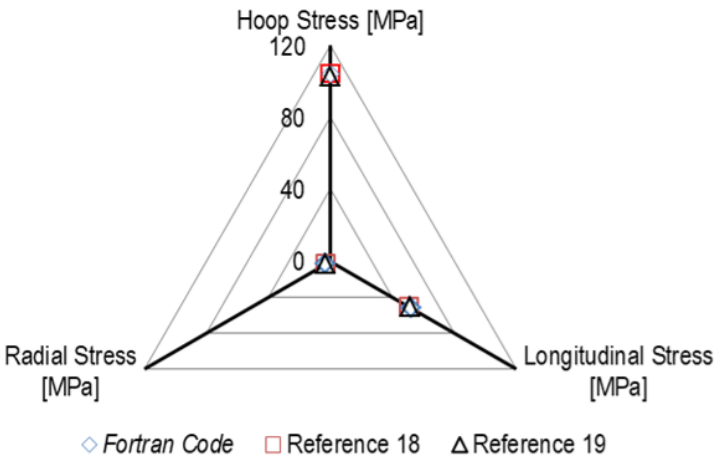

a)

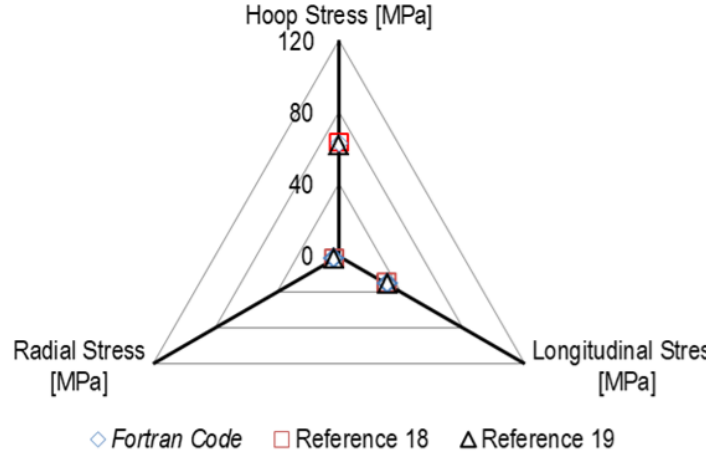

b)

Figure 7. Evaluation of calculation results from literatures for cylindrical shell of: a) upper portion;b) lower portion.

\section{CONCLUSIONS}

This study has demonstrated the usefulness of Fortran code of RPV_RDE.exe in conducting the analysis on the cylindrical shell design of RPV for RDE. The validated results as shown in simulation cases have proven that the accurate design calculations of the model geometry and dimensions of cylindrical shell could be achieved. This information is vital in the design process analysis where the values and results obtained from the calculations, could be used in fulfilling design output specification according to the selected materials of carbon steel SA516-70. Finally, all design calculations meet the safe requirements and the minimum wall thicknesses are $60 \mathrm{~mm}$ and 100 $\mathrm{mm}$ for the upper portion and lower portion, respectively.

\section{AKNOWLEDGEMENTS}

The part of the research is supported by Ministry of Research, Technology and Higher Education of Indonesia under Program of Insinas-Flagship for RDE BATAN 2018 to 2019, and the author would also like to acknowledge the support given by PTKRN management.

\section{REFERENCES}

[1] S. Sudadiyo, T Taryo, T. Setiadipura, A. Nugroho and Krismawan, "Preliminary Design of Reactor Pressure Vessel for RDE", International Journal of Mechanical Engineering and Technology, vol. 9, no.6, pp. 889-898, 2018.

[2] T. Taryo, Ridwan, G. R. Sunaryo and M. Rachmawati, "The Strategy to Support HTGR Fuels for the 10 MW Indonesia's Experimental Power Reactor (RDE)", Urania, vo.24, no.1, pp. 1-16, 2018.

[3] R. Frith and M. Stone, "A Proposed New Pressure Vessel Design Class", International Journal of Pressure Vessels and Piping, vo.13, pp. 4-11, 2016.

[4] M. E. Scari, A. L. Costa, C. Pereira, C. E. Velasquez and M. A. F. Veloso, "HTR Steady State and Transient Thermal Analyses", International Journal of Hydrogen Energy, vol.41, pp. 7192-7196, 2016.

[5] J.H. Yoon and B.S. Lee, "Comparison of Applicability of Current Transition Temperature Shift Models to SA533B-1 Reactor Pressure Vessel Steel of Korean Nuclear Reactors", Nuclear Engineering and Technology, vol.49, pp. 1109-1112, 2017.

[6] Z. Zhang, Y. Dong, F. Li, Z. Zhang, H. Wang, X. Huang, H. Li, B. Liu, X. Wu, H. Wang, X. Diao, H. Zhang and J. Wang, "The Shandong Shidao Bay 200 MWe High-Temperature Gas-Cooled Reactor Pebble-Bed Module Demonstration Power Plant: An Engineering and Technological Innovation", Engineering, vol.2, pp. 112-118, 2016.

[7] Y. Weng, H. Wang, B. Cai, H. Gu and H. Wang, "Flow Mixing and Heat Transfer in Nuclear Reactor Vessel with Direct Vessel Injection", Applied Thermal Engineering, vol.125, pp. 617-632, 2017. 
Jurnal Iptek Nuklir Ganendra

Ganendra Journal of Nuclear Science and Technology

Vol. 24 No. 1, January 2021: 1-10

[8] I. Tavakkoli, M.R. Kianoush, H. Abrishami and X. Han, "Finite Element Modeling of a Nuclear Containment Structure Subjected to High Internal Preesure", International Journal of Pressure Vessels and Piping, vol. 153, pp. 59-69, 2017.

[9] S. Sudadiyo. "Preliminary Design of RDE Feedwater Pump Impeller", Tri Dasa Mega, vol.20, no.1, pp. 1-12, 2018.

[10] R.S. Khurmi and J.K. Gupta, Machine Design, 14th Edition, Eurasia Publishing House, 2005.

[11] K. Osakada, "History of Plasticity and Metal Forming Analysis", Journal of Materials Processing Technology, vol. 210, pp. 1436-1454, 2010.

[12] Y.M. Shabana, A. Elsawaf, H. Khalaf and Y. Khalil, "Stresses Minimization in Functionally Graded Cylinders Using Particle Swarm Optimization Technique", International Journal of Pressure Vessels and Piping, vol. 154, pp. 1-10, 2017.

[13] J.F. Mao, J.W. Zhu, S.Y. Bao, L.J. Luo and Z.L. Gao, "Creep Deformation and Damage Behaviour of Reactor Pressure Vessel under Core Meltdown Scenario ", International Journal of Pressure Vessels and Piping, vol. 139, pp. 107-116, 2016.

[14] Y. Zhu, Q. Ma, J. Zhang, W. Tang and Y. Dai, "Opening Reinforcement Design and Buckling of Spherical Shell Subjected to External Pressure", International Journal of Pressure Vessels and Piping, vol.15, pp. 2936, 2017.

[15] A. Benslimane, S. Bouzidi and M. Methia, "Displacements and Stresses in Pressurized Thick-Walled FGM Cylinders: Exact and Numerical Solutions", International Journal of Pressure Vessels and Piping, vol. 168, pp. 219-224, 2018.

[16] ASME. Boiler and Pressure Vessel Code. In: Section III Division 5, New York, 2015.

[17] P. Alvaredo, P. Bruna, D. Crespo and E. Gordo, "Influence of Carbon Content on Microstructure and Properties of a Steel Matrix Cermet", International Journal of Refractory Metals and Hard Materials, vol. 75, pp. 78-84, 2018.

[18] P. Dzierwa, D. Taler and J. Taler, "Optimum heating of cylindrical pressure vessels", Forsch Ingenieurwes, vol. 79, pp. 163-173, 2016.

[19] J. Jelwan, M. Chowdhury and G. Pearce, "Creep Life Design Criterion and Its Applications to Pressure Vessel Codes", Materials Physics and Mechanics, vol. 11, pp. 157-182, 2011. 